\title{
A Brief study of the Application of Blended Learning in Higher Vocational College English Teaching
}

\author{
Xu Jin, Zhang Haolong, Man Xiaoping \\ Jining Polytechnic, Jining, Shandong Province 370800, China
}

Keywords: blended learning; e-learning; vocational English teaching

\begin{abstract}
The 21st century in human age is entering into information age. With the development of educational informatization, our teaching extends from traditional classroom to outside classroom world of internet. Blended learning is a kind of teaching model which combines the traditional face-to-face teaching and e-learning. And it is an important research of English teaching reform in vocational college. On one hand, this teaching model emphasizes the cultivation of the learner's autonomy and initiative; on the other hand, it gives play to the teacher's leading function in teaching process. In this paper, we explores the application of blended learning in higher vocational English teaching, and proposes some concrete teaching model to making contribution on improvement of higher vocational English teaching, so as to enhance the teaching quality.
\end{abstract}

\section{Introduction}

With the fast development of internet technology, a great change takes place in students' way of learning. Campus network, multimedia classroom and online course have continued to introduce new forms. The internet technology has played an important role in education. Since 1990s, E-learning which depends on internet information technology has been used widely in college English teaching. However, it is becoming apparent that without a teacher's guidance it is difficult for learner to master the knowledge systematically. Vocational college students is a special learner group with distinct features, such as relatively weak learning autonomy, relatively weak learning initiative and relatively weak learning perseverance. But at the same time, they are eager to gain the positive recognition from teachers and their peers. Neither traditional class teaching nor e-learning can satisfy the need of vocational college students. Thus Blended leaning combines the advantages of face-to-face teaching and e-learning to obtain better teaching results, becoming the new direction of teaching in vocational college English.

\section{The Concept of Blended Learning}

Definitions. Blended learning is not a new term, the concept of blending different learning experiences has been existing ever since human started thinking about learning and teaching. What makes it new is the infusion of internet technologies into learning and teaching process. Colis and Moonen (2001) defined blended learning as a hybrid of traditional face-to-face and online learning so that instruction occurs both in classroom and online. Thus blended learning is a flexible teaching approach to course design that employs the blending of different times and places for learning, offering the convenience if some online learning materials without loss of face-to-face instruction.

In China, it was Professor He Kekang in Beijing Normal University who introduced the concept of "Blended learning”. He believes that B-learning is a new teaching mode which combines the advantages of traditional learning method and e-learning (digital or online learning). That is to say, blended learning not only brings teachers' leading role in guiding and monitoring teaching process into full play, but also embodies the student's central position in the learning process by stimulating their initiative, autonomy, and creativity.

The Essence of Blended Learning. Blended learning is a teaching philosophy. Any learning model has both advantages and disadvantages. No single learning model can solve all problems and 
meet the needs of teaching and learning at any time. Only by organically combining different learning or teaching models and giving full play of their respectively advantages can the learning and teaching achieve the ideal efficiency. Blended learning is such a teaching philosophy. Especially at this internet information era, we can deeply feel that education has gotten giant change due to the application of internet, which changes the traditional forms of English teaching. Only integrating the online or e-learning and traditional teaching forms can teaching process achieve the best outcomes.

Blended learning is a new learning and teaching model. Under this model, the student is the main body, and the teacher is the main guide in the learning and teaching process. The teacher's leading role lies in the illustration of knowledge points and controlling and monitoring the teaching procedure, teaching design and material arrangements in the face-to-face classroom teaching. While the students' main learning body position is reflected in freedom and autonomy in the learning process and activities. Students can chose learning materials, learning methods, learning tools and set their own learning pace besides finishing teacher's assignment, which the students' initiative, enthusiasm and autonomy are greatly motivated.

Blended learning is multidimentional system. On micro level, the dimension refers to various factors in education system, which composed of teachers, students, teaching materials and teaching media. These elements are not isolated components in teaching system. They are interacted with each other. Only by integrating them into an organic whole can we optimize the teaching and learning effect. On mid-level, Blended learning is a hybrid of different learning patterns and pedagogies. These learning patterns include traditional classroom teaching, collaborative learning, project-based learning, task-based learning, etc. The choice of learning patterns and pedagogies depends on the teaching contents, teaching goal and the learners. On macro level, Blended learning is the integration of traditional classroom teaching and e-learning which combines their respective advantages. In this model, students gain the priority as the body of learning supervised by the teachers.

\section{The Traditional Education Situation in Vocational College English Teaching}

Necessity of English Teaching Reform in Vocational College. The main task of English teaching in higher vocational colleges is to cultivate students' professional ability and job ability. Mastering English, this universal language, is a great help for their future career. At the same time, English communication ability is essential for future international talents. While a large amount of students in higher vocational colleges have difficulties of speaking English. As a matter of fact, for vocational college students, oral English communication ability is the most important. The lack of spoken English will limit their professional development to a certain extent. In the future English teaching, we should connect the learners' professional knowledge with English instruction, improving the students' English communication skills to enhance their international competitiveness.

Problems in Higher Vocational English Teaching. In the past 30 years, the English teaching in college has gained steady development. At the same time, the government put forward a lot of policies which is beneficial to English teaching. More and more people and students realize the importance of English. There is a good atmosphere for students to study. However, there are still some problems about English teaching in higher vocational college.

Students lack interest in traditional English classroom teaching. Traditional vocational English teaching is so called teacher-centered teaching model. The teacher is the main body in the teaching process, while the students are in the passive position. This face-to-face classroom teaching is restricted to time and space, which is not suitable for the students to set their own leaning paces. Students passively participate in the learning process which is designed by their teacher, which is not helpful for the realization of life-long education. And also the teaching content is limited to the textbooks to some extents. The students have little freedom to select the learning materials which greatly frustrated their enthusiasm. As the internet technology develops greatly, our English teaching needs reform and innovation. Only by enriching the teaching preparation, adopting 
different teaching and learning patterns, integrating with various internet learning styles can the teacher arouse the students' interest to obtain ideal teaching results.

Students have relatively low Conversational English Skills. In traditional English teaching process, the teacher emphasizes more on the theories than practice; pay more attention on knowledge than skills. So there is a common phenomenon among the vocational students, that is, they are much weak in English communication, leading to their lack of confidence in English conversation. Fluent oral English is a required skill for higher vocational college students, which can adopt them to the society well, because international participation in future career is inevitable with the increasingly development of international co-operations. Based on the investigation on English communication needs among higher vocational college students, we can figure out that although the higher vocational college students lack confidence in English conversation, they have a strong desire for English communication, which is Optimistic for us teachers to launch reform in higher vocational college English teaching. Combining face-to-face classroom and online learning, the teacher can illustrate the language points and basic language theories in physical classroom teaching, and create English communication environment for students by adopting various leaning patterns in classroom. At the same time, the students can choose their learning materials related to teaching topic and their majors, put English into practice through online learning.

\section{The Application of Blend-learning in Vocational College English Teaching}

In the Blended learning model, the teachers play a leading role to monitor the learning and teaching process, while the students are the main body and center. On the internet-based teaching platform, the teachers give the assignment and communicate with the students on line; the students check the assignment, learning autonomously, collaborate with their classmates and finish the assignment. In classroom teaching, the students rise questions, present their (teamwork) assignment, exchange ideas with teachers and classmates; while the teachers solve the questions, illustrate the key and difficult points, check the students' assignment and give periodical assessment. The whole learning process is student-centered, which not only cultivates the students' communicating and teamwork ability but also arouses their learning interest and enthusiasm. The following discussed blended learning model has three teaching organization forms: face-to-face classroom learning, online self-learning and collaborative learning based on internet technology. There are four stages for implementation.

Teaching Preparations and Students Guidance before Class. In order to organize efficient teaching and learning activities, the teachers should make a careful analysis of teaching objectives and the target learners. When teaching vocational college students, we may find that they stay at different English levels, which results from their high school learning experiences. So the target learner analysis is significant. Based on the learner analysis, we can set up achievable objectives. Then the teachers should make a careful section of appropriate teaching resources, such as selected textbooks, some English learning websites, magazines, etc. All the resources are presented in forms of text, picture, audio files, videos, flash, etc. Computer are used to play videos and PPT while some internet chatting tools are used for online learning and interaction between teachers and students. At this stage, assignment or tasks are placed by the teacher. Then the students begin their learning process as completion of tasks one by one under the guidance of teacher.

Face-to-face Classroom Teaching and Learning. The classroom in blended learning model is more student-centered than the traditional teacher-centered classroom. The students participate in the class with the questions and doubts. They have strong desire of acquisition and performance, which is a big challenge to the teachers' teaching methods. That requires that the teachers not only illustrate the key and difficult knowledge points but also help students to find the problems and solve the problems. So the classroom activities consist of face-to-face instruction and face-to-face learning.

In face-to-face instruction process, because the higher vocational college students are relatively weak in English, the teachers pay emphasize on the imparting basic English knowledge to the students through a traditional teaching forms, such as sharing background materials, text analysis, 
etc. The main teaching method is the blending of teachers' instruction and the students' discussion with the help of multi teaching media. The students accumulate words and sentence patterns, improve textual analysis ability in this process.

Face-to-face learning is a process that the students present their learning achievements and learning tasks and the teachers give feedback and give new assignments. When students' performances come to an end, feedback could be given through group discussion, teachers' evaluation, peer evaluation and self-evaluation. This evaluation process will help students reflect their learning process, which is helpful to cultivating students' metacognition ability. At the end of class teachers tell the students to prepare neat learning task, then the students will collect useful resources through online learning, or teachers give them samples to imitate. Face-to-face learning ends after students finish presentation of previous learning task and teachers give new assignments.

Students' Online Learning. Online learning consists of autonomous learning and guided learning. Autonomous learning gives students more freedom to set up their learning paces. They can use rich internet resources and download enormous English learning materials according to their own needs. Teacher can recommend some English leaning websites, such as Hujiang English(http://www.hjenglish.com/), Ted, etc. Guided learning is a learning process under teachers' supervision and help. When the students meet problems, students could discuss with classmates or consult teachers through QQ community, Wechat community or teachers' blog. With such kind of internet or mobile tools, teachers could give the students some concrete guidance and monitor their learning on line.

Blended Assessment and modification. The assessment traditional teaching is composed of regular performance assessment and final exam assessment. While the grade in final exam lies could occurs by chance, which could not be authentic. But the assessment of blended learning is a combination of formative assessment and summative assessment, traditional assessment and online assessment, self-assessment and teachers' assessment, which could help the teachers and students clearly realize the achievements and deficiencies in the teaching and learning process. So, modification could be done for further learning.

\section{Conclusion}

The rapid development of internet information technology and the demand for skilled talents in the 21st century have brought opportunities and challenges as well to higher vocational college English teaching reform. Traditional teacher-centered classroom teaching is greatly restricted to time and space, which neglects the students' needs and personal differences. While completely online learning could not achieve ideal learning effect without the teachers' guidance and supervision. That is to say, we must launch teaching reform which could gives full display of the teachers' leading role of guiding ,enlightening, and monitoring the while teaching and learning process, and also emphasizes the students' main body position and stimulates their autonomy, positiveness, creativeness and differentiation. That is blended learning model. In this paper, we discussed the concept of blended learning, analyzed the situation of present higher vocational college English teaching situation and proposed the application of blended learning model which consists of four stages. Such teaching model could greatly arouse the students' interest and initiatives in English learning, which put the students-centered teaching ideology into practice.

\section{References}

[1] Colis. B. \& Moonen. J. Fexible Learning in a digital world: Experiences and expectations [M]. Lodon: Kogan-Page 2001.

[2] He Kekang, New Development of Educational Technology Theory from Blended Learning Perspective [J], Journal of National Academy of Education Administration, 2005,9:37-48.

[3] Cui Xiaoxia, Sun Yingling, B-aided and blog-aided English Learning Model Research [J], Computer Society, International Conference on Computer Science and Electronics Engineering, 
2012.

[4] Bian Xiaoping, The Application of Blended Teaching Model in Art Middle School Students' English Learning [D], Henan University, 2015.

[5] Guo Yanqing, On the Application of Blended Learning to College English Teaching-Taking Pubic Art Deparment of Nanfang College at Yat-sen University as an Example [J], Journal of Jilin EngeerningNormal University, 2016,3:60-62. 